\title{
Globalisation and Its Influence on Mathematics Education in Secondary Schools in Akwa Ibom State, Nigeria
}

\author{
Udofa, Ataetima I. \\ Maths/Statistics Department, \\ Akwa I bom State College of Arts and Science, Nung Ukim, Ikono-Nigeria
}

Udo, Imo E.

Akwa Ibom State College of Arts and Science, Nung Ukim, Ikono. Nigeria

\section{Doi:10.5901/jesr.2013.v3n6p33}

\begin{abstract}
The study investigated globalization and its influence on mathematics education in secondary schools in Akwa Ibom State, Nigeria. The study determined how globalization influences mathematics contents, teaching methods and instructional resources. The research questions were to what extent does globalization influences mathematics contents, teaching methods and instructional resources. Descriptive survey design was employed in which five (5) secondary schools were choosen and ten SSII students were randomly selected from each of the schools making a total of fifty (50) students. A 22-item studied questionnaire comprising of the following sub-sections: mathematics contents, mathematics teaching methods and mathematics instructional resources were used to collect the needed data for the study. The collected data were analysed using chi-square analysis, and the hypotheses that there is no significance influence of globalization on mathematics contents, teaching methods and instructional resource were tested at 0.05 level of significance. The result shows that globalisation has not significantly influenced the three variables- mathematics contents, teaching methods and instructional resources. It was recommended among others, that technology based instruction should be adopted by mathematics teachers and government should build well-equipped e-library in all the States to improve online learning.
\end{abstract}

Keywords: Globalisation, Mathematics Education, Mathematics Contents, Teaching Methods, and Instructional Resources.

\section{Introduction}

Globalisation is a process of interaction among the people, companies and government of different nations, a process driven by international trade and investment and aided by information technology. It is a process of making something generally accepted all over the world. Globalisation has unified the entire world into one small village with common socio-economic, political, cultural and educational systems (Wokocha, 2011). With the world educational system, every individual or society must operate within the world order to meet the challenges of globalization.

Globalisation processes have linked education to technological and economic development. For instance, global collaboration is essential for moving mathematics education forward in this globalised world and at the same time avoiding the colonialism of the past and allowing the discipline to play its role in bridging the ever increasing gap between countries (Atweh $\&$ Clarkson, 2005). The culture of globalization has equally engendered the Millennium Development Goals 
strategies (MDGs), which seek to address issues of poverty, education, equality, wealth and environment and the Education For All Goals to be achieved by year 2015 (Obomanu \& Adaramola, 2011). In view of these, globalization has deeply affected mathematics education in schools since mathematics is regarded as the peak for decision making.

With the discovery of computer and internet which make globalization possible, the nature of teaching and learning is changing from traditional learning to electronic learning method. The change from teacher-centered to learner-centered has created a close connection between knowledge construction and reflective action among students and the need to embrace information technologies. Education and training need to keep up with the emergence of new technologies so that students learning mathematics in Nigeria can fit in with other students in another country.

Odili (2006) opines that the education of any nation is given impetus by the quality of educational programmes that are available and the zeal with which they are implemented. Through the internet, globalization allows the access to ideas on new things and best practices in all areas of human endeavour. Odili conceptualises mathematics as the queen of the sciences and that no nation can hope to achieve any measure of scientific or technological advancement without proper foundation in school mathematics. Mathematics itself is very important for the study of other social sciences. It is associated with the development of technology because engineers cannot do without mathematics.

White (2007) discussed how many of the patterns and practices of everyday life are shifting and changing at different rates in response to the powerful global processes that often appear beyond immediate local control, belief or even comprehension. Globalisation is a force reorganizing the world's economy and help to increase the body of knowledge and quality of life. Knowledge is fundamental to globalization and globalization in turn has influence on the transfer of knowledge. Therefore the concept of mathematics learning and knowledge delivery needs to be changed.

As the world is advancing, the use of traditional learning gadgets and learning style has changed to the use of technology/electro-mechanical devices for societies to acquire the right information skills, attitudes and techniques for sustainable growth and development. In this case, learning is easily linked across countries thereby maintaining learning standard between societies to meet the challenges of globalization. According to Wokocha (2011), the globalised world was made possible by the discovery of the computer and internet which has made the world virtual by transmitting information across the globe in a matter of micro-seconds.

In Nigeria, mathematics does not appear to be in tune with the developments across the world because its pedagogical approach has not changed substantially over the years. Schools do not integrate new technologies into teaching and learning. Students do not learn how to use and integrate the new technologies in order to fit in wherever they find themselves. Communication infrastructure is inadequate for our students. Most learners in remote areas cannot have access to computers or get connected when they want to learn after school hours. It has been observed that learners do not appear to use their mobile phone for learning, and the use of computer and internet is not embraced in a higher rate particularly for learning mathematics.

Since the need for knowledge and technology-based personnel in the area of mathematics is very necessary in this era of globalization, it therefore becomes imperative and expedient to find out if there is any influence of globalization on teaching and learning of mathematics in secondary schools.

This research in general terms seeks to determine the influence of globalization on mathematics education in secondary schools. Therefore, the purpose of this study is to determine how globalization influences mathematics contents, teaching method and instructional resources. In the same vein, the following research questions were developed to direct the study. To what extent does globalization influence mathematics contents, teaching method and instructional resources? The hypotheses adopted for this study is there is no significant influence of globalization on mathematics contents, teaching method and instructional resources? 


\section{Globalisation and Mathematics Contents}

Cabillan (2011) opines that globalization in the $21^{\text {st }}$ century is reaching almost all countries. Few places can elude contemporary trends and innovative practices are seen to spread even faster due to modern technology. Mathematics has played important role in the school curriculum in every country. It acts as a means of access to other courses thereby helping to develop many professionals. The inexorable transformation of consciousness brought on by globalization alters the content and contours of education, as schools take on an increasingly important role in the process. (Wokocha 2011), and Rutkowski \& Rutkowski, (2008) argue that it is reasonable to expect that what students know (based on curriculum) is one type of outcome for which an increase in similarity across countries may be expected. Therefore it is wise for us to promote the international curriculum standards that might positively influence mathematics learning. Rutkwoski et al asserted that, as the role and impact of technology continue to increase in society and in the workplace, the concepts, processes and skills of science and mathematics are likely to become even more highly valued and the importance of these subjects in school curricula to become even greater.

Cabillan (2012) has asserted a necessity of addressing the need to shift the culture of mathematics learning to suit the features of globalization. In this case more specific contents should covers cognitive processes in hypermedia and multimedia learning, social issues in computer-supported collaborative learning, motivation and emotion in blended learning and elearning.

Rutkowski \& Rutkowski (2008) provides a comparison and contrast of two theories of the impacts of global forces on education. First, a Common World Educational Culture (CWEC) theory, developed over a number of years by John Meyer and Colleagues and students at Standford University, argues that a universal model of education is being developed primary by global institutions.

Therefore mathematical academic bodies should try to make changes in the area of contents design, instructional resources and teaching method which should be well incorporated for the training of youths.

\section{Globalisation and Mathematics Teaching Method}

Cabillan (2011) has asserted that the classical way to deliver lectures needs to be changed, minimizing the use of old textbooks and offering a very lively guiding programme based upon various information sources, with revised teaching notes and opening new windows to appreciate the context of students and their creativity as individuals and as a group.

Carnoy \& Rhoten (2002) opine that the way knowledge is delivered in the classroom is an important aspect of knowledge production and the classroom seems largely untouched. Wokocha (2011) also asserted that equity pedagogy creates an environment in which students can acquire, integrate and produce knowledge and envision new possibilities for the use of knowledge for societal change. It challenges the idea of instruction as transmission of knowledge where the professor is the source of knowledge and wisdom and the students are passive recipients.

\section{Globalisation and Mathematics Instructional Resources}

Cabillan (2011) asserted that education is very gradual in its adoption of changes despite the presence of technology within their reach. They are rarely used. Yushau (2006) also foundout that, Mathematics professors perceive computers as a positive tool that can enhance the teaching and learning process but putting such perception into practice tells a different story.

Cabillan (2012) investigated the response of some members of the faculty of mathematics department of selected universities to questions an issue regarding the pervasiveness of globalization. Four top universities of the Philippines were included in the study. The study 
employed a case type qualitative research design. The study considers the area of instructional design, faculty and research. Findings have shown a very low level of the use of technology in the classrooms.

In view of these, the new technologies should be highly embraced by mathematics learners such as making use of mobile phone in learning, the use of computer, internet, hypermedia and multimedia facilities should be encouraged. Some techniques have been developed to have access to information on the internet such as communicating with colleagues on mathematics topics over the internet, sharing information on mathematics through e-mail, downloading of information into Digital Video Disk (DVD) to distribute to schools which help students without computer to use television and study which make them active in learning. Olaniyan \& Obadara (2006), assert that with the increasing capacity of information and communication technologies, there is a rise in new learning opportunities beyond the traditional bookteacher model. These factors cannot be denied because it is the main factor in increasing the level of collaboration as globalization comes to stay.

According to Castells (1996) as cited in Olaniyan \& Obadara (2006), a substantive progress in implementation of information and communications for that matter progress in quality of life and development cannot be achieved without preparing people for a knowledge society. Learning takes place through communication. Therefore students should make use of information and communications technology to broaden learning skills.

Globalisation has many important implications for the learning of mathematics in schools. Based on these facts, it of interest to examine the influence of globalization on mathematics education in schools.

\section{Research Method}

The research design adopted for this study is descriptive survey. This design helps the researcher in obtaining the vital facts and opinions from students.

The population of the study consists of all senior secondary two students in all the secondary schools in Uyo. To obtain the sample five (5) students were randomly chosen from each of the ten schools selected for the study. Therefore, a total of fifty (50) students in SS2 formed the sample for the study.

The study area is Uyo Local Government Area in Akwa Ibom State, Nigeria. This local government area is the central part of Akwa Ibom State and serves as the State capital. It is thickly populated and has five clans with twenty two public and private secondary schools. But this study is restricted to only ten (10) secondary schools in the State.

A questionnaire was designed, validated and their reliability determined before they were used. The above instrument was used to collect the data used for the study. The administration and collection of all the necessary information were done during the normal class hours. Chi-square test $\left(\chi^{2}\right)$ was used to see if there exist any significant influence in the globalization of mathematics contents, teaching methods and instructional resources in students learning.

\section{Results}

Table 1: Result of Chi-Square Analysis of the Influence of Globalization on Mathematics Contents

\begin{tabular}{|c|c|c|c|c|c|c|c|c|c|c|c|c|}
\hline \multirow{2}{*}{$\mathbf{S} / \mathbf{N}$} & \multirow{2}{*}{ Items } & \multicolumn{2}{|c|}{ SA } & \multicolumn{2}{|r|}{ A } & \multicolumn{2}{|c|}{ D } & \multicolumn{2}{|c|}{ SD } & \multirow[b]{2}{*}{ Df } & \multirow{2}{*}{$\begin{array}{c}\chi^{2} \\
-\mathrm{cal}\end{array}$} & \multirow{2}{*}{$\begin{array}{l}\chi^{2} \\
-\mathrm{cri}\end{array}$} \\
\hline & & fo & fe & Fo & $\mathrm{Fe}$ & fo & fe & Fo & fe & & & \\
\hline 1 & $\begin{array}{l}\text { Our Mathematics teacher always asks us } \\
\text { to browse contents from internet and } \\
\text { compare with the ones given }\end{array}$ & 11 & 12.5 & 15 & 12.5 & 15 & 12.5 & 9 & 12.5 & 3 & 2.16 & \\
\hline 2 & Mathematics contents in Nigeria is too & 11 & 12.5 & 10 & 12.5 & 11 & 12.5 & 18 & 12.5 & 3 & 3.28 & \\
\hline
\end{tabular}




\begin{tabular}{|c|l|c|c|c|c|c|c|c|c|c|c|c|}
\hline & Simple compared with other countries & & & & & & & & & & & \\
\hline 3 & $\begin{array}{l}\text { We usually browse new topics from } \\
\text { internet }\end{array}$ & 13 & 12.5 & 12 & 12.5 & 14 & 12.5 & 11 & 12.5 & 3 & 0.40 \\
\hline 4 & $\begin{array}{l}\text { We get some mathematics textbooks from } \\
\text { internet }\end{array}$ & 6 & 12.5 & 7 & 12.5 & 18 & 12.5 & 19 & 12.5 & 3 & 11.60 \\
\hline 5 & $\begin{array}{l}\text { Our teacher introduces us to DVD on } \\
\text { mathematics topics }\end{array}$ & 4 & 12.5 & 7 & 12.5 & 19 & 12.5 & 20 & 12.5 & 3 & 16.08 & \\
\hline 6 & $\begin{array}{l}\text { We watch the teaching of mathematics on } \\
\text { television }\end{array}$ & 11 & 12.5 & 13 & 12.5 & 8 & 12.5 & 18 & 12.5 & 3 & 4.24 & 7.815 \\
\hline & Total & $\mathbf{5 6}$ & $\mathbf{7 5}$ & $\mathbf{6 4}$ & $\mathbf{7 5}$ & $\mathbf{8 5}$ & $\mathbf{7 5}$ & $\mathbf{9 5}$ & $\mathbf{7 5}$ & $\mathbf{1 4}$ & $\mathbf{1 5 . 4 0}$ & $\mathbf{2 3 . 6 8 5}$ \\
\hline
\end{tabular}

Table 1 reveals that the calculated $\chi^{2}$ value of 15.40 is less than the critical $\chi^{2}$ value of 23.685 with 14 degree of freedom at 0.05 level of significance. The result is not significant. Therefore, the hypothesis that there is no significant influence of globalization on mathematics contents is retained.

The table also shows that non of the items on influence of globalization on mathematics contents is significant when the calculated $\chi^{2}$ values of $2.16,3.28,0.40,11.60,16.08,4.24$ are compared with the critical $\chi^{2}$ value of 7.815 at 0.05 level of significance. This result means that globalization has no significant influence on the contents of mathematics in the secondary school system.

Table 2: Result of Chi-Square Analysis of the Influence of Globalization on Mathematics Teaching Method

\begin{tabular}{|c|c|c|c|c|c|c|c|c|c|c|c|c|}
\hline \multirow{2}{*}{$\mathbf{S} / \mathbf{N}$} & \multirow{2}{*}{ Items } & \multicolumn{2}{|c|}{ SA } & \multicolumn{2}{|c|}{ A } & \multicolumn{2}{|c|}{ D } & \multicolumn{2}{|c|}{ SD } & \multirow[b]{2}{*}{ dff } & \multirow{2}{*}{\begin{tabular}{c|}
$\chi^{2}$ \\
$-\mathrm{cal}$
\end{tabular}} & \multirow{2}{*}{$\begin{array}{c}\chi^{2} \\
\text {-cri }\end{array}$} \\
\hline & & fo & fe & fo & $\mathrm{Fe}$ & Fo & $\mathrm{fe}$ & Fo & fe & & & \\
\hline 7. & $\begin{array}{l}\text { Our teacher uses drill and practice method } \\
\text { in teaching mathematics. }\end{array}$ & 11 & 12.5 & 15 & 12.5 & $11 \mid$ & 12.5 & 13 & 12.5 & 3 & 0.88 & \\
\hline 8. & $\begin{array}{l}\text { Inductive-deductive method is used by our } \\
\text { teacher to solve mathematics problems. }\end{array}$ & 10 & 12.5 & 21 & 12.5 & 12 & 12.5 & 7 & 12.5 & 3 & 8.72 & \\
\hline 9. & $\begin{array}{l}\text { The teacher uses analytic and synthetic } \\
\text { methods to analyse some mathematics } \\
\text { topics. }\end{array}$ & 8 & 12.5 & 8 & 12.5 & 9 & 12.5 & 25 & 12.5 & 3 & 16.72 & \\
\hline 10 & $\begin{array}{l}\text { Our teacher uses computer assisted } \\
\text { instruction in teaching mathematics. }\end{array}$ & 6 & 12.5 & 13 & 12.5 & 16 & 12.5 & 15 & 12.5 & 3 & 4.88 & \\
\hline 11 & $\begin{array}{l}\text { Our teacher applies electronic (e) learning } \\
\text { in teaching mathematics. }\end{array}$ & 2 & 12.5 & 18 & 12.5 & 16 & 12.5 & 14 & 12.5 & 3 & 12.40 & \\
\hline 12 & $\begin{array}{l}\text { Our teacher uses simulation method to } \\
\text { teach mathematics. }\end{array}$ & 7 & 12.5 & 7 & 12.5 & 13 & 12.5 & 23 & 12.5 & 3 & 13.68 & \\
\hline 13 & $\begin{array}{l}\text { The teaching methods adopted by my } \\
\text { teacher are students centered. }\end{array}$ & 10 & 12.5 & 14 & 12.5 & 14 & 12.5 & 12 & 12.5 & 3 & 0.88 & 7.815 \\
\hline & Total & & 87.5 & & 37.5 & 91 & 87 & 109 & 87 & 14 & 20.80 & 23.68 \\
\hline
\end{tabular}

Table 2 reveals that the calculated value of 20.80 is less than the critical $\chi^{2}$ value of 23.685 with 14 degree of freedom at 0.05 level of significance. The result is not significant. Therefore, the hypothesis that there is no significant influence of globalization on mathematics teaching method is retained.

The table also shows that non of the items on influence globalization on mathematics teaching method is significant when the calculated $\chi^{2}$ values of $0.88,8.72,16.72,4.88,12.40$, 
$13.68,0.88$ are compared with the critical $\chi^{2}$ value of 7.815 at 0.05 level of significance. This result means that globalization has no significant influence on the mathematics teaching method in the secondary school system.

Table 3: Result of Chi-Square Analysis of the Influence of Globalization on Mathematics Instructional Resources

\begin{tabular}{|c|c|c|c|c|c|c|c|c|c|c|c|c|}
\hline \multirow{2}{*}{$\mathrm{S} / \mathrm{N}$} & \multirow{2}{*}{ Item } & \multicolumn{2}{|c|}{ SA } & \multicolumn{2}{|c|}{ A } & \multicolumn{2}{|c|}{$\mathrm{D}$} & \multicolumn{2}{|c|}{ SD } & \multirow[b]{2}{*}{ Df } & \multirow{2}{*}{$\begin{array}{l}\chi^{2} \\
-\mathrm{cal}\end{array}$} & \multirow{2}{*}{$\begin{array}{l}\chi^{2} \\
- \text { cri }\end{array}$} \\
\hline & & Fo & fe & fo & $\mathrm{Fe}$ & fo & fe & fo & $\mathrm{Fe}$ & & & \\
\hline 14 & $\begin{array}{l}\text { Our teacher uses computer to teach } \\
\text { mathematics }\end{array}$ & 2 & 12.5 & 15 & 12.5 & 16 & 12.5 & 17 & 12.5 & 3 & 11.92 & \\
\hline 15 & $\begin{array}{l}\text { Our teacher uses projector to teach } \\
\text { mathematics }\end{array}$ & 9 & 12.5 & 12 & 12.5 & 16 & 12.5 & 13 & 12.5 & 3 & 2.00 & \\
\hline 16 & All my teachers are computer literates & 11 & 12.5 & 10 & 12.5 & 20 & 12.5 & 9 & 12.5 & 3 & 6.16 & \\
\hline 17 & $\begin{array}{l}\text { We use twitter to communicate with } \\
\text { my teacher at home }\end{array}$ & 4 & 12.5 & 11 & 12.5 & 13 & 12.5 & 22 & 12.5 & 3 & 13.20 & \\
\hline 18 & $\begin{array}{l}\text { There is mathematics laboratory in } \\
\text { my school }\end{array}$ & 12 & 12.5 & 4 & 12.5 & 11 & 12.5 & 23 & 12.5 & 3 & 14.80 & \\
\hline 19 & $\begin{array}{l}\text { I interact with students in another } \\
\text { country through e-mail }\end{array}$ & 12 & 12.5 & 13 & 12.5 & 12 & 12.5 & 13 & 12.5 & 3 & 0.08 & \\
\hline 20 & $\begin{array}{l}\text { I have my personal computer for } \\
\text { learning mathematics }\end{array}$ & 15 & 12.5 & 10 & 12.5 & 15 & 12.5 & 10 & 12.5 & 3 & 2.00 & \\
\hline 21 & $\begin{array}{l}\text { Our school has Information and } \\
\text { Communication Technology (ICT) } \\
\text { centre }\end{array}$ & 17 & 12.5 & 13 & 12.5 & 12 & 12.5 & 8 & 12.5 & 3 & 3.28 & \\
\hline 22 & $\begin{array}{l}\text { I use handset to search for } \\
\text { information in mathematics }\end{array}$ & 13 & 12.5 & 16 & 12.5 & 12 & 12.5 & 9 & 12.5 & 3 & 2.00 & 7.815 \\
\hline & Total & 95 & 112.5 & 104 & 112.5 & 127 & 112.5 & 124 & 112.5 & 19 & 12.40 & 30.144 \\
\hline
\end{tabular}

Table 3 reveals that the calculated $\chi^{2}$ value of 12.40 is less than the critical $\chi^{2}$ value of 30.144 with 19 degree of freedom at 0.05 level of significance. The result is not significant. Therefore, the hypothesis that there is no significant influence of globalization on mathematics instructional resources is retained.

The table also shows that non of the items on globalisation influence on mathematics instructional resources is significant when the calculated $\chi^{2}$ values of $11.92,2.00,6.16,13.20$, $14.80,0.80,2.00,3.28,2.00$ are compared with the critical $\chi^{2}$ value of 7.815 at 0.05 significance level. This result means that globalization has no significant influence on the mathematics teaching method in the secondary school system.

\section{Discussion of Findings}

The finding on Hypothesis 1 reveals that there is no significant influence of globalization on mathematics contents. This is in consonance with finding by Rutkwoski \& Rutkwoski (2008) which says that, policy and curriculum may be impacted more by regional forces than global forces, which mean that students are yet to feel the impact of globalization on mathematics contents.

The test of Hypothesis 2 reveals that there is no significant influence of globalization on mathematics teaching methods. This is in agreement with the findings of International Mathematics Study (SIMS) who performed a comprehensive survey of the teaching and learning of mathematics in the schools of twenty-four countries around the world. The result revealed that American students were distinctly mediocre in mathematics when compared to their peers in most other 
countries. (Vernille 2002). This therefore means that there is no influence of globalization on mathematics teaching and learning.

The test of Hypothesis 3 reveals that there is no significant influence of globalization on mathematics instructional resources. This agrees with the findings of Cabillan (2012) which shows a very low level of the use of technology in the classrooms from the four departments studied. This therefore means that there is no influence of globalization on mathematics instructional resources.

\section{Educational Implication of Findings}

From the findings, it implies that with globalisation which enhances the adoption of good modern techniques of instructional delivery through the use of mathematics hypermedia and multimedia and demonstration procedure, students can become versatile in their approach to solving mathematics problems. It also implies that with the use of internet, computer, mobile and information technology in learning mathematics students' potentials of understanding the concepts of mathematics will increase. It also reveals that with the adoption of globalization in mathematics teaching and learning, students are likely to develop interest in the subject.

\section{Conclusions}

The study took a careful look at globalization and its influence on mathematics education of students in secondary schools. It has been realized that there is no significant influence of globalisation on mathematics contents, teaching methods and instructional resources. This is as a result of low level use of computers technology in teaching. And it has reduced students' knowledge and skill compared to what and how it should be achieved. Hence, appropriate methods of teaching and the use of Technology based Instruction be embraced as these would help reduce the rate of globalisation influence on mathematics education. Also the framework for what students need to know to meet their potential for learning challenging mathematics in the school should be provided.

\section{Recommendations}

From the study, it is recommended that more specific contents should be covered and schools should embrace the new teaching techniques. Government should provide to all schools computers, multimedia facilities, good communication network system, etc. for students quality learning.

- Information and Communication Technology Centre (ICTC) should be built in all the schools.

- Teachers should embrace computer and technology based instruction in lessons delivery which will help us move toward blackboard-less classrooms.

- Parents should help their wards to have their own personal computer to help them interact with colleagues and teachers online after schools hours.

- Students should make use of their mobile technology, computer and internet to search for information on mathematics.

- Government should build well-equipped e-library in all the States to improve online learning.

\section{References}

Atweh, B. \& Clarkson, P. (2005). More perspectives on the impact of globalisation on mathematics education in higher education. Retrieved on $14^{\text {th }}$ November, 2011 from www.merga.net.au

Cabillan, M. L. (2011). Changing landscape of mathematics in the Philippine: lesson from globalization. Retrieved $9^{\text {th }}$ May 2012 from http://vlir-piuc.slu.edu.ph 
Carnoy, M. \& Rhoten, D. (2002). What does globalization mean for educational change? A comparative approach. Comparative Education Review 46(1). Retrieved 14 ${ }^{\text {th }}$ November, 2011 from http://education. eastwestcenter.org.

Namukasa, I. (2004). School mathematics in the era of globalization. Retrieved $9^{\text {th }}$ May, 2012 from http://andromeda.rutgers.edu.

Obomanu, B. J. \& Adaramola, M. O. (2011). Factor related to under achievement in science technology and mathematics education (STME) in secondary school in Rivers State, Nigeria. World Journal of Education 1(1). Retrieved $14^{\text {th }}$ November, 2011 from www.sciedu.ca

Obuah, E. (2011).Challenges in the era of globalization. International Academy of African Business and Development, vol.12. Edmonton, Canada. Retrieved $9^{\text {th }}$ May, 2012 from www.aabd.org.

Odili, G. (2006). Mathematics in Nigeria secondary schools: A teaching perspective. (Rev.ed.). Nigeria: Rex Charles \& Patrick Limited.

Olaniyan, D. A. \& Obadara, O. E. (2006). Globalisation and Nigerian educational System: Opportunities and challenges. International Journal of African and African American Studies 5(2). Retrieved $14^{\text {th }}$ November, 2011 from https://ojcs. siue.edu

Rutkwoski L. \& Rutkwoski D. (2008). Globalization in Education: An empirical look at globalization in education. An Example with Trends in International Mathematics and Science Study Mathematics data. Retrieved $9^{\text {th }}$ May, 2012 from www.iea.nl

Sidhu, K. S. (1995). The teaching of mathematics. (Fourth Revised Edition). India: Sterling Publishers Private Limited.

Vernille, K. (2002). Why are mathematics students falling behind their international peers. National Education Policy Center. Retrieved $19^{\text {th }} \mathrm{J}$ une, 2012 from www.users. math.umd.edu

White, A. (2007). An Australian mathematics educator in South-East Asia. Transnational Curriculum Inquiry. Retrieved $15^{\text {th }}$ November, 2011 from http://nitinet.library.ubc.ca

Wokocha, A. M. (2011). Globalisation, education reforms and knowledge economy in a multicultural society. First National Conference, Institute of Education, University of Port Harcourt.

Yushau, B. (2006). Computer attitude, use, experience, software familiarity and perceived pedagogical usefulness: The case of mathematics professors Eurasia. Journal of Mathematics, Science and Technology Education 2(3). Retrieved $9^{\text {th }}$ May 2012 from www.msnbc.msn.com 